\title{
CORPORATE SOCIAL RESPONSIBILITY STRATEGI KOMUNIKASI PERUSAHAAN MIGAS
}

\author{
Mohammad Hidayaturrahman \\ Universitas Wiraraja Sumenep \\ hidayatsahabatkita2016@gmail.com
}

\begin{abstract}
This research was conducted to find out what kind of communication strategy of oil and gas company in Sumenep, Madura East Java. This research method using single case study with qualitative descriptive approach. This research was conducted by using object observation and interviews to various informants directly related. From the research, it is found that PT Kangean Energi Indonesia (KEI) oil and gas company through single corporate social responsibility (CSR) program model becomes one of effective means of communication. The lack of corporate social responsibility (CSR) single program is not able to cover many problems faced by the community simultaneously, takes a long time to be able to solve other problems. So there needs to be additional funding for the sustainability of the program, and the acceleration of community needs fulfillment.
\end{abstract}

Keywords: CSR, Strategy, and Communication.

\begin{abstract}
Abstrak
Penelitian ini dilakukan untuk mengetahui seperti apa strategi komunikasi perusahaan migas di Sumenep, Madura Jawa Timur. Metode penelitian ini menggunakan studi kasus tunggal (single case study) dengan pendekatan kualitatif deskriptif. Penelitian ini dilakukan dengan menggunakan observasi objek dan wawancara kepada berbagai informan yang terkait secara langsung. Dari penelitian yang dilakukan diperoleh hasil bahwa, perusahaan minyak dan gas (Migas) PT Kangean Energi Indonesia (KEI) melalui model corporate social responsibility (CSR) program tunggal kelistrikan menjadi salah satu sarana komunikasi yang efektif. Kekurangan corporate social responsibility (CSR) program tunggal adalah tidak dapat mengcover banyak persoalan yang dihadapi oleh masyarakat secara bersamaan, membutuhkan waktu lama untuk bisa menyelesaikan persoalan lain. Sehingga perlu ada penambahan dana bagi keberlanjutan program tersebut, dan percepatan pemenuhan kebutuhan masyarakat.
\end{abstract}

Kata Kunci : CSR, strategi, komunikasi 
JURNAL NOMOSLECA

Volume 3, Nomor 2, Oktober 2017

\section{PENDAHULUAN}

Berbagai ragam bentuk dan model corporate social responsibility (CSR) yang dijalankan oleh perusahaan, mulai dari yang sekadar berbentuk amal (charity) hingga program yang bersifat elitis. Kegiatan ini dilakukan oleh kelompok atau tokoh elit yang tinggal di dekat lokasi perusahaan, atau diberikan kepada pihak pemerintah di daerah. Setiap pilihan bentuk dan model corporate social responsibility (CSR) yang dipilih oleh perusahaan pada hakikatnya adalah pilihan untuk dapat menjalin komunikasi yang baik dengan publik, pada berbagai segmen dan lapisan.

Hasil penelitian Fauzi (2015) CSR merupakan salah satu bentuk dari tanggungjawab perusahaan kepada pihak eksternal perusahaan yakni stakeholdernya, terutama komunitas atau masyarakat baik itu disekitar wilayah operasional perusahaan maupun di luar perusahaan. CSR yang efektif dan sesauai dengan kondisi lokasi adalah yang fokus pada peningkatan kolektibilitas serta pembinaan dan monitoring kepada mitra binaan agar mampu mandiri.

Program kepedulian sosial perusahaan (CSR) menjadi salah satu pilihan yang dinilai mampu menjembatani kebutuhan publik dengan citra perusahaan yang perlu untuk berkomunikasi yang baik dengan publik, terutama warga yang tempat tinggalnya berdekatan dengan lokasi perusahaan.

Dengan begitu akan diketahui bahwa strategi komunikasi tidak hanya melalui media massa, namun juga bisa dalam bentuk pembuatan program secara langsung berdasarkan kebutuhan masyarakat. Selain itu, penelitian ini ditujukan untuk mengetahui model CSR yang mampu meningkatkan efektivitas komunikasi.

Perusahaan minyak dan gas (Migas) PT Kangean Energi Indonesia (KEI) menggunakan strategi komunikasi dengan jalan membangun infrastruktur dan fasilitas publik di wilayah Kepulauan Raas, Kecamatan Raas, Kabupaten Sumenep, Jawa Timur, dalam bentuk pembangunan fasilitas listrik untuk sembilan desa yang ada di wilayah Kecamatan Raas, sejak tahun 2013 lalu.

Secara khusus KEI membuat program CSR dengan model tunggal kelistrikan dengan alasan bahwa program tersebut menyasar kebutuhan mendasar warga masyarakat, dan belum dipenuhi oleh pihak penyedia. Sehingga dengan menyediakan listrik terhadap warga, secara otomatis memenuhi kebutuhan dasar warga.

Untuk lebih mendekatkan pelayanan, KEI bekerjasama dengan tokoh masyarakat dan kepala desa juga pemerintah daerah dalam realisasi dan pelaksanaan teknis penyediaan listrik tersebut. Hal ini sekaligus menjadi salah satu tanda bahwa komunikasi perusahaan migas dengan berbagai segmen dan lapisan berjalan dengan baik, tanpa kendala, dari sejak tahun 2012 lalu, program CSR tunggal kelistrikan terus berjalan hingga kini.

\section{TINJAUAN PUSTAKA}

\section{Difusi Inovasi Komunikasi Pembangunan}

Teori difusi inovasi berkembang lebih jauh dimana fokus kajian tidak hanya dikaitkan dengan proses perubahan sosial 
dalam pengertian sempit. Topik studi atau penelitian difusi inovasi mulai dikaitkan dengan berbagai fenomena kontemporer yang berkembang di masyarakat. Berbagai perpektif pun menjadi dasar dalam pengkajian proses difusi inovasi, seperti perspektif ekonomi, perspektif "market and infrastructure", hingga program CSR (Brown, 1981).

Dalam Nasution (1995) tahapan dari proses pengambilan keputusan inovasi mencakup:

1. Tahap Munculnya Pengetahuan (Knowledge) ketika seorang individu (atau unit pengambil keputusan lainnya) diarahkan untuk memahami eksistensi dan keuntungan/manfaat dan bagaimana suatu inovasi berfungsi

2. Tahap Persuasi (Persuasion) ketika seorang individu (atau unit pengambil keputusan lainnya) membentuk sikap baik atau tidak baik

3. Tahap Keputusan (Decisions) muncul ketika seorang individu atau unit pengambil keputusan lainnya terlibat dalam aktivitas yang mengarah pada pemilihan adopsi atau penolakan sebuah inovasi.

4. Implementasi (Implementation), ketika sorang individu atau unit pengambil keputusan lainnya menetapkan penggunaan suatu inovasi.

5. Tahapan Konfirmasi (Confirmation), ketika seorang individu atau unit pengambil keputusan lainnya mencari penguatan terhadap keputusan penerimaan atau penolakan inovasi yang sudah dibuat sebelumnya.
Dalam komunikasi dikenal teori difusi inovasi yang dicetuskan oleh sosiolog Perancis, Gabriel Tarde pada 1903. Teori ini menjelaskan suatu inovasi disampaikan melalui saluran-saluran tertentu kepada sekelompok anggota dari sistem sosial. Menurut Rogers (1971) teori difusi inovasi merupakan bentuk komunikasi yang bersifat khusus dan berkaitan dengan penyebaran beberapa pesan berisi gagasan-gagasan baru. Katena itu, teori ini sering dikaitkan dengan proses pembangunan masyarakat. Sesuai dengan pemikiran Rogers, dalam proses difusi inovasi terdapat empat elemen pokok, yaitu:

Pertama, inovasi. Gagasan, tindakan, atau barang yang dianggap baru oleh seseorang. Dalam hal ini, kebaruan inovasi diukur secara subjektif menurut pandangan individu yang menerimanya. Jika suatu ide dianggap baru oleh seseorang maka ia adalah inovasi untuk orang itu. Konsep 'baru' dalam ide yang inovatif tidak harus baru sama sekali. Kedua, saluran komunikasi. Alat untuk memperhatikan dua cara bagaimana penelitian telah memperkuat kembali perbaikan dalam konseptualisasi masalah. Dinyatakan secara sederhana, kedua cara itu telah menekankan bahwa adopsi seharusnya diteliti sebagai suatu proses dan bukannya sebagai suatu peristiwa, dan bahwa difusi seharusnya dianalisis sebagai suatu proses sosial dan bukan sekedar jumlah adopsi individual, Bagi peneliti, dan mungkin bagi individu yang bersangkutan, adopsi inovasi bisa nampak sebagai suatu peristiwa atau tindakan (Nasution, 1995: 13).

Ketiga, jangka waktu. Proses keputusan inovasi, dari mulai seseorang mengetahui sampai memutuskan untuk menerima atau menolaknya, dan 
pengukuhan terhadap keputusan itu sangat berkaitan dengan dimensi waktu. Paling tidak dimensi waktu terlihat dalam (a) proses pengambilan keputusan inovasi, (b) keinovatifan seseorang: relatif lebih awal atau lebih lambat dalam menerima inovasi, dan (c) kecepatan pengadopsian inovasi dalam sistem sosial. Keempat, sistem sosial. Kumpulan unit yang berbeda secara fungsional dan terikat dalam kerjasama untuk memecahkan masalah dalam rangka mencapai tujuan bersama (Rogers \& Shoemaker, 1971).

Salah satu definisi difusi inovasi dalam taraf perkembangan ini antara lain dikemukakan Parker dalam Putri (2013: 64-65), yang mendefinisikan difusi sebagai suatu proses yang berperan memberi nilai tambah pada fungsi produksi atau proses ekonomi. Dia juga menyebutkan bahwa difusi merupakan suatu tahapan dalam proses perubahan teknik (technical change). Menurutnya difusi merupakan suatu tahapan dimana keuntungan dari suatu inovasi berlaku umum. Dari inovator, inovasi diteruskan melalui pengguna lain hingga akhirnya menjadi hal yang biasa dan diterima sebagai bagian dari kegiatan produktif.

\section{Coorporate Social Responsibility (CSR)}

Rahman, dkk (2011) menjelaskan Corporate Social Responsibility (CSR) adalah sebuah program yang mengimplentasikan tanggung jawab social perusahaan kepada masyarakat luas, Namun demikian, CSR buakn sekedar aksi filantropi dan charity semata, tetapi lebih luas dari itu mencakup seluruh aspek ssosial,lingkungan, bahkan ekonomi. CSR seharusnya menjadi bagian penting dari strategi perencanaan perusahan.
Sedangkan dalam penelitian Rasyid, dkk (2015) CSR selalu melekat dengan isu pemberdayaan, dimana pemberdayaan masyarakat dan citra postif adalah yang diinginkan dari program CSR perusahaan. Faktor yang mempengaruhi CSR yang efektif adalah komunikator, pesan, saluran dengan pemberdayaan masyarakat dan citra perusahaan.

\section{Corporate Social Responsibility} (CSR) atau Tanggung Jawab Sosial Perusahaan (TJSP) merupakan salah satu isu yang mengglobal di samping isu demokrasi dan hak asasi manusia. Menurut Suharto, CSR merupakan sebuah tuntutan global dimana keberhasilan perusahaan (korporasi) tidak hanya dinilai dari kinerja keuangan dan pemasaran produknya saja tetapi juga terhadap kinerja sosial dan lingkungannya (Suharto, 2008).

CSR dan pembangunan berkelanjutan menjadi penting jika dikaitkan dengan isu lingkungan. Tuntutan untuk melakukan CSR menjadi tak terelakkan, ketika fakta menunjukkan konsumsi korporasi terhadap penggunaan sumber dayaalam (SDA) mencapai lebih dari $30 \%$ dari apa yang dapat disediakan oleh alam/lingkungan (Rahman, 2009 : 44).

Dari hasil penelitian Sunaryo (2013) dalam artikel CSR dalam perspektif pembangunan berkelanjutan, Corporate Social Responsibility (CSR) ideal dalam perspektif pembangunan berkelanjutan dan penyusunan program-program CSR berorientasi pada pembangunan berkelanjutan. ingin mencapai corporate sustainability dalam membuat program CSR di samping harus memperhatikan aspek ekonomi dansosial, juga harus memperhatikan aspek lingkungan sehingga 
akan terjaga eksistensi perusahaannya dan sekaligus kelestarian lingkungannya. Artinya, program-program CSR perlu diselaras dengan prinsip-prinsip pembangunan berkelanjutan sebagaimana yang diamanatkan dalam UUD 1945.

Pendapat tersebut diperkuat dari Yamien (2008), menekankan pada aspek perusahaan harus memperhatikan semua hubungan, tidak hanya oleh masyarakat tetapi juga dengan pelanggan, karyawan, masyarakat, pemilik, pemerintah, pemasok dan bahkan pesaing

\section{METODE PENELITIAN}

Penelitian ini menggunakan metode studi kasus, karena penelitian ini bertujuan untuk mengamati peristiwa nyata yang terjadi pada strategi komunikasi PT Kangean Energi Indonesia (KEI) untuk menjalin hubungan baik dengan warga yang berada di wilayah Kepulauan Raas, Kabupaten Sumenep. Hal yang diamati dalam penelitian ini adalah terkait dengan data dan fakta yang ditemukan dalam pelaksanaan corporate social responsibility (CSR), program tunggal kelistrikan. Penelitian ini menyediakan gambaran yang relatif lengkap mengenai apa yang terjadi pada saat penelitian dilakukan.

Dalam Bungin (2015) desain penelitian (research design) yang dipilih dalam penelitian ini adalah single-case study dengan pendekatan kualitatif deskriptif. Dengan demikian, penelitian ini dilakukan melalui pengamatan langsung (observasi) terhadap objek pada saat penelitian dilakukan dengan menggunakan observasi dan wawancara kepada pihak yang terlibat, baik dari unsur pemerintah, pihak swasta dan masyarakat sebagai pengelola, maupun perwakilan masyarakat sebagai pengguna (user) listrik yang dibangun, disediakan dan difasilitasi oleh pihak perusahaan.

Fokus penelitian ini adalah pada pelaksanaan CSR program tunggal di Kepulauan Raas, Kecamatan Raas, Kabupaten Sumenep, Jawa Timur, terutama pada program pengadaan listrik bagi pulau-pulau yang ada di Kepulauan Raas, Kecamatan Raas, Kabupaten Sumenep, Jawa Timur. Program pengadaan listrik yang dilakukan sejak tahun 2013 lalu hingga saat ini. Sedangkan penelitian sendiri dilakukan selama dua pekan, pada awal hingga pertengahan Agustus 2017.

Pengumpulan data dilakukan dengan cara observasi yang dilakukan langsung oleh peneliti, untuk melihat aktivitas dan kehidupan warga di Kepulauan Raas, Kecamatan Raas. Selain melakukan observasi, peneliti juga melakukan wawancara langsung dengan informan kunci yang terdiri dari pelaksana program kelistrikan, bagian ESDM Sekretariat Daerah, Pemerintah Kabupaten Sumenep, kepala desa, dan tokoh masyarakat.

Data yang dikumpulkan di lapangan kemudian dilakukan pengecekan ulang (recheking), dengan melakukan verifikasi (triangulasi) terhadap informan lain yang juga menjadi pihak yang berkaitan langsung dengan masalah kesenjangan pembangunan yang terjadi di wilayah Kepulauan Raas, baik wakil rakyat, maupun aktivis lembaga swadaya masyarakat (LSM). Data yang diperoleh kemudian disusun dengan menggunakan teknik pengolahan data, mereduksi data, menyajikan data yang sudah diperoleh, dan menarik kesimpulan. 
JURNAL NOMOSLECA

Volume 3, Nomor 2, Oktober 2017

HASIL PENELITIAN DAN PEMBAHASAN

Dalam memilih saluran komunikasi, sumber paling tidak perlu memperhatikan (a) tujuan diadakannya komunikasi dan (b) karakteristik penerima. Jika komunikasi dimaksudkan untuk memperkenalkan suatu inovasi kepada khalayak yang banyak dan tersebar luas, maka saluran komunikasi yang lebih tepat, cepat dan efisien, adalah media massa. Tetapi jika komunikasi dimaksudkan untuk mengubah sikap atau perilaku penerima secara personal, maka saluran komunikasi yang paling tepat adalah saluran interpersonal.

Charles Wright selanjutnya mengatakan, kita semata-mata akan Strategi yang digunakan dan dikembangkan oleh perusahaan migas PT KEI yang beroperasi di Kepulauan Raas, Kabupaten Sumenep, Madura, Jawa Timur mengacu pada

Program penunjang operasi (PPO) perusahaan migas di Kabupaten Sumenep merupakan nama lain dari corporate social responsibility (CSR). Untuk perusahaan migas yang beroperasi di wilayah Kepulauan Raas, Kabupaten Sumenep, Jawa Timur, model program CSR yang direalisasikan dalam bentuk program tunggal kelistrikan. Jadi setiap tahun, dana CSR yang dikeluarkan oleh perusahaan migas PT Kangean Energi Indonesia (KEI) digunakan untuk membangun infrastruktur dan fasilitas listrik yang ada di Kepulauan Raas, Kecamatan Raas.

Pelaksanaan program pengadaan listrik dilakukan secara bertahap untuk seluruh pulau dan desa yang ada di Kecamatan Raas, Kabupaten Sumenep. Jumlah keseluruhan warga Kecamatan Raas sebesar 40 ribu jiwa yang terdiri dari
15 ribu kepala keluarga (KK) yang mendiami sebanyak sembilan desa dan

$$
\text { Pembangunan fasilitas listrik }
$$

dimulai pada tahun 2013 di Pulau GoaGoa, Kecamatan Raas, Kabupaten Sumenep, Jawa Timur. Pemilihan Pulau Goa-Goa berdasarkan pada titik terdekat dengan lokasi eksplorasi dan produksi migas yang dilakukan oleh PT KEI dengan sumur yang bernama Terang Sirasun, yang paling dekat ke Pulau Goa-Goa. Sehingga Pulau Goa-Goa disebut dengan ring satu. Setelah pulau terdekat tersedia listrik, program pembangunan listrik terus berpindah ke pulau dan desa lain sesuai dengan asas kedekatan dengan lokasi kegiatan perusahaan migas, begitu seterusnya.

Untuk listrik yang dibangun oleh perusahaan seluruh kebutuhan listrik disediakan oleh perusahaan, mulai dari mesin pembangkit (genset), sesuai dengan besarnya kebutuhan warga di kepulauan, kemudian kabel yang digunakan untuk mengalirkan listrik ke rumah-rumah warga, jalan dan fasilitas umum, termasuk lampu di setiap rumah. Setiap rumah disediakan tiga titik lampu, sedangkan lampu yang disediakan oleh perusahaan satu saja. Keseluruhan pengadaan itu warga tidak dipungut biasa sama sekali, alias gratis. Artinya, hingga listrik menyala di rumah warga, tidak dikenakan biaya satu rupiah pun, semua ditanggung dan dibiayai oleh perusahaan diambilkan dari dana corporate social responsibility (CSR) program tunggal kelistrikan yang dijalanlan oleh perusahaan. Begitu pula dengan fasilitas umum, seperti tempat ibadah dan lainnya, dipasang lampu sesuai kebutuhan.

Setelah lampu terpasang dan sudah menyala, pengelolaan listrik diserahkan kepada kelompok masyarakat (Pokmas) yang dibentuk langsung oleh masyarakat 
dan disepakati oleh tokoh masyarakat bersama kepada desa. Pokmas inilah yang mengelola pelaksanaan, pemeliharaan dan perawatan listrik yang telah diserahkan oleh perusahaan. Pokmas kemudian mengenakan biaya kepada warga yang menjadi pelanggan listrik per lampu sebesar Rp 25 ribu. Jumlah tersebut jauh lebih murah daripada biaya yang ditetapkan oleh pihak swasta yang juga menyediakan lampu genset di daerah kepulauan lainnya yang mengenakan biaya hingga Rp 50 ribu per lampu. Biaya yang dikumpulkan digunakan untuk operasional seperti membeli solar, oli, termasuk biaya perawatan dan perbaikan mesin genset.

Salah satu Pokmas yang berhasil mengembangkan listrik di kepulauan adalah Pulau Komerian yang berhasil mengumpulkan dana hingga Rp 30 juta dari iuran yang dikeluarkan oleh warga. Rencananya, dana yang berhasil dikumpulkan dan ditabung akan digunakan untuk membeli mesin baru, jika suatu saat mesin yang ada saat ini sudah rusak dan tidak lagi dapat digunakan. Sehingga warga tidak lagi tergantung kepada bantuan dari perusahaan, maupun pemerintah.

Pihak perusahaan menunjuk seorang petugas yang diberi tanggung jawab untuk melakukan supervisi dan pengawasan serta kordinasi kepada beberapa Pokmas yang menjadi penanggung jawab dan pengelola listrik di masing-masing pulau, minimal satu bulan satu kali. Dari kegiatan tersebut terpantau secara rutin kendala dan persoalan apa yang dihadapi oleh pengelola, dan didiskusikan untuk dicarikan solusi bersama pihak perusahaan. Untuk selanjutnya kegiatan tersebut dilaporkan oleh perusahaan kepada Pemerintah
Kabupaten Sumenep dalam rapat PPO yang digelar setahun sekali.

Pembangunan listrik di wilayah Kepulauan Raas ini berdampak positif bagi perekonomian dan pendidikan warga. Sebagian warga yang memiliki uang membeli kulkas yang digunakan untuk membuat es yang selanjutnya dijual kepada nelayan kecil yang hendak pergi menangkap ikan. Selain itu, es yang diproduksi juga dijual kepada pedagang es dan warga umum. Selain kios atau toko yang biasanya hanya berjualan dari pagi sampai sore hari, dengan adanya lampu penerangan, mereka juga buka hingga malam hari. Hal ini tentu saja berdampak pada semakin meningkatnya pendapatan pedagang.

Pada sektor pendidikan, para siswa yang selama ini terkendala lampu penerangan untuk belajar pada malam hari, kini sudah leluasa untuk mengaji setelah magrib, baik di rumah maupun musolla dan belajar materi pelajaran sekolah pada malam hari, baik perorangan maupun secara kelompok. Artinya siswa yang belajar pada malam hari sudah tidak mengalami kendala sama sekali. Begitu pun warga bisa menikmati siaran televisi.

Mulai tahun 2016 lalu, wilayah daratan Kecamatan Raas yang terdiri dari tujuh desa sudah mulai dibangun fasilitas listrik berupa tiang penyangga kabel untuk dialiri listrik. Setelah tiang penyangga sebanyak 600 tiang dengan tinggi masingmasing tiang 12 meter, baru akan dipasang kabel yang akan menghantarkan aliran listrik. Sehingga, secara bertahap Raas daratan akan diterangi listrik yang menyala secara merata menerangi warga yang terdiri dari tujuh desa. Pemerintah Kabupaten Sumenep, melalui Wakil Bupati menargetkan listrik di daratan Raas akan menyala pada tahun 2019, dengan total 
biaya sekitar Rp 14 miliar. Sehingga, dengan menyalanya lampu di daratan Raas secara rata dan menyeluruh, berarti persoalan listrik di Kepulauan Raas akan selesai diatasi dengan model pelibatan swasta di dalam pelaksanannya.

Program corporate social responsibility (CSR) sudah mulai digagas dan dijalankan oleh PT Kangean Energi Indonesia (KEI) sejak tahun 2013 lalu, dengan menggunakan dana murni $100 \%$ dari perusahaan. Jika dirinci mulai tahun 2013 lalu, dana yang dikeluarkan oleh pihak swasta untuk membangun listrik di Kepulauan Raas hingga tahun 2017 telah menghabiskan dana sebesar Rp 7.707.000.000 (tujuh miliar tujuh ratus tujuh juta rupiah).

Rincian kegiatan, dan lain-lain dari corporate social responsibility (CSR) model tunggal dapat dilihat pada tabel berikut:

Tabel : Rincian kegiatan corporate social responsibility (CSR) PT KEI

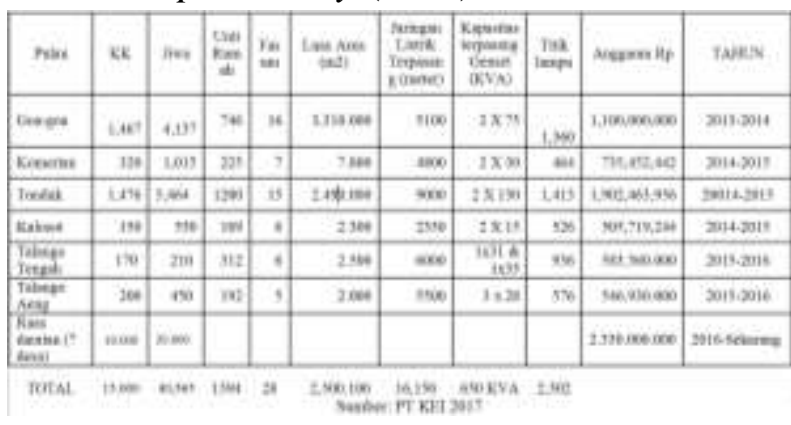

Model dan bentuk serta alur pelaksanaan corporate social responsibility (CSR) bentuk tunggal bisa dimulai dari pembentukan tanggung jawab sosial program penunjang operasi (OPP) oleh Bupati Sumenep yang dipimpin oleh Sekretaris Daerah (Sekda), sedangkan anggotanya terdiri dari tokoh masyarakat di level kecamatan Raas dan sembilan kepala desa di satu kecamatan yang wilayahnya menjadi tempat kegiatan eksplorasi dan produksi perusahaan migas (PT KEI).

Selanjutnya, tahapan pelaksanaan dimulai dengan perencanaan (planning) yang dilakukan oleh para kepala desa bersama tokoh dan camat dalam forum musyawarah rencana pembangunan desa (MUSRENBANGDES) yang dilanjutkan dengan musyawarah rencana pembangunan kecamatan (MUSRENBANGCAM). Hasil dari MUSRENBANGCAM kemudian diajukan ke perusahaan migas, dari perusahaan migas diajukan ke Satuan Kerja Khusus Pelaksana Kegiatan Usaha Hulu Minyak dan Gas Bumi (SKK Migas). Setelah mendapat persetujuan dari SKK Migas terkait dengan besaran dana yang akan dikeluarkan oleh perusahaan migas, hasilnya dibawa ke rapat komite program penunjang operasi (PPO) yang dihadiri oleh seluruh pemangku kebijakan (stake holders), terdiri dari para kepala desa, tokoh masyarakat, camat, bupati, wakil bupati, Ketua Dewan Perwakilan Rakyat Daerah (DPRD) sekretaris daerah, kepala dinas terkait, pihak perusahaan dan SKK Migas. Di akhir acara biasanya dilakukan penandatanganan nota kesepakatan program dan berita acara pelaksanaan para pihak terkait. Selain itu ada juga penandatanganan pakta integritas yang dilakukan oleh kepala desa dan kelompok yang menjadi pelaksana kegiatan, sebagai bentuk komitmen untuk menjalankan kegiatan sesuai dengan ketentuan yang berlaku. Kegiatan ini biasanya dilakukan di Surabaya. Seluruh biaya penyelenggaraa kegiatan ini ditanggung oleh pihak perusahaan (PT KEI) yang berlangsung selama dua hari pada September setiap tahun.

Setelah itu baru tahapan realisasi dilakukan dengan pengadaan barang. Untuk barang yang nominalnya kurang 
dari Rp 100 juta dilaksanakan langsung oleh perusahaan, sedangkan barang yang nominalnya lebih dari Rp 100 juta dilaksanakan oleh kelompok masyarakat (Pokmas) yang sudah disepakati oleh masyarakat bersama kepala desa dan camat, dan didampingi oleh pihak perusahaan. Proses pengadaan barang dari awal hingga akhir melibatkan perusahaan, mulai dari pembelian, mobilisasi dan pengangkutan hingga pemasangan melibatkan perusahaan. Setelah semua siap untuk digunakan (ready to use) dilakukan serah terima kepada pihak desa dan Pokmas pengelola, sebagai bentuk penyerahan tanggung jawab penuh keberlangsungan dari program corporate social responsibility (SCR) dari perusahaan kepada masyarakat. Dan untuk selanjutnya masyarakat yang mengelola secara penuh, pihak perusahaan hanya mendampingi saja.

Jika digambarkan dalam bentuk skema, maka alur pelaksanaan corporate social responsibility (CSR) perusahaan migas di wilayah Kepulauan Raas, Kabupaten Sumenep, Jawa Timur sebagai berikut:

Tabel alur pelaksanaan corporate social responsibility (CSR) PT KEI

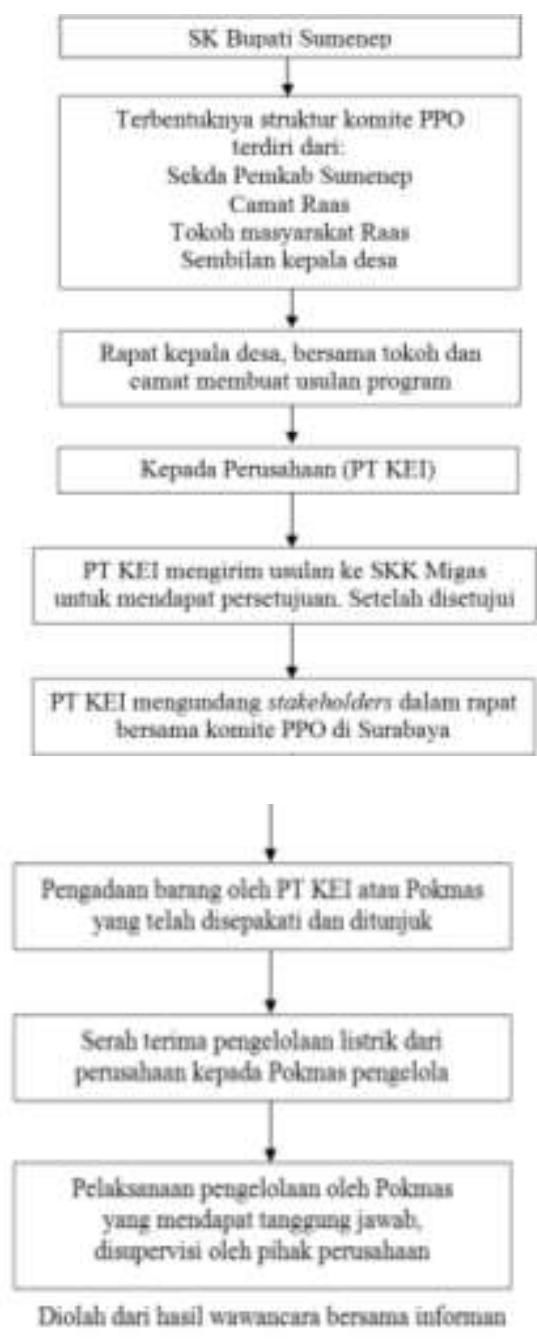

Pelaksanaan corporate social responsibility (CSR) PT KEI model tunggal kelistrikan di wilayah Kepulauan Raas, Kabupaten Sumenep, Jawa Timur antara lain :Penandatanganan berita acara dan pakta integritas di Surabaya, Tes dan serah terima listrik kepada Pokmas dan desa di Pulau Komerian dan Aktivitas warga dan anak-anak di Pulau Komerian pada malam hari setelah listrik menyala.

\section{PENUTUP}

\section{Simpulan}

Model corporate social responsibility (CSR) bentuk tunggal ternyata bisa menjadi media untuk 
menjalin hubungan baik antara perusahaan dengan masyarakat. Hal ini terjadi, karena dana CSR yang dialokasikan oleh perusahaan bisa fokus ke satu bidang listrik dirasakan bentuk manfaatnya oleh publik, sehingga publik bisa merasakan manfaat positif bagi program tersebut. Terlebih lagi, program digagas berdasarkan aspirasi yang disampaikan oleh masyarakat dan tokoh dalam rapat formal maupun nonformal.

Model ini bisa menjadi satu contoh efektifnya penggunaan dana corporate social responsibility dalam membentuk citra positif perusahaan migas di mata masyarakat tempat lokasi perusahaan menjalankan kegiatan usaha.

Model yang fokus dan terarah bisa mengatasi satu persoalan secara secara bertahap. Namun tidak bisa mengatasi beberapa persoalan yang dihadapi warga dalam waktu yang bersamaan dan relatif singkat. Sebab dana yang dialokasikan oleh perusahaan juga terbatas.

\section{Saran}

1. Penelitian lanjutan untuk menjawab kekurangan model dari penelitian ini. Penelitian menjawab tentang persoalan yang dihadapi warga dalam waktu yang bersamaan dan relatif singkat.

2. Model ini hanya melibatkan pelaksana CSR saja, sehingga menjadibahan kajian selanjutnya untuk merumuskan model yang melibatkan manajemen dan stakeholder supaya lebih menyatu.

\section{DAFTAR PUSTAKA}

Rogers \& Shoemaker,

Communication of Innovations.

London: The Free Press

Bungin, Burhan. 2015. Metodologi Penelitian Kualitatif. Depok : Rajagrafindo.

Fauzi, Fiqih. 2015. Implementasi CSR Pada Program Kemitraan dan Binaan Lingkungan Perum Percetakan Uang Republik Indonesia. http://repository.uinjkt.ac.id/dspace/bit stream/123456789/31869/1/FIQIH\%2 0FAUZI-FDK.pdf. Diakses 21 Oktober 2017.

Nasution, Z. 1995. Komunikasi Inovasi. Jakarta: Universitas Terbuka, Depdikbud.

Brown, Lawrence A. 1981. Innovation Diffusion: A New Perpevtive. New York: Methuen and Co.

Putri, I Dewa Ayu Hendrawathy. 2013. Difusi Inovasi Dalam Komunikasi Pemasaran Politik Indonesia. Jurnal Communication Vol. 4 No.2 Oktober 2013.

file:///F:/jurnal\%20communicolog/JN \%203\%20no2/DIFUSI\%20INOVASI $\%$ 20DALAM\%20KOMUNIKASI\%20 PEMASARAN\%20POLITIK\%20IND ONESIA.pdf. Diakses 11 Oktober 2017.

Rahman, Reza. 2009. Corporate Social Responsibility: Antara Teori dan Kenyataan. Yogyakarta: MedPress.

Rasyid, Anual., dkk. 2015. Komunikasi Dalam CSR Perusahaan : Pemberdayaan Masyarakat dan Citra Positif. MIMBAR, Vol. 31, No. 2. Desember, 2015.

Suharto, Edi. Corporate Social

Responsibility : Konsep dan Perkembangan Pemikiran". Makalah 
disampaikan pada Workshop

Tanggungjawab Sosial Perusahaan, Universitas Islam Indonesia (UII), Yoyakarta, Tanggal 6-8 Mei 2008.

Yamien, S (2008). CSR dan Konsep Pembangunan yang Berkelanjutan. Jurnal Yustitia. Indramayu: Universitas Wiralodra.

Sunaryo (2013). Corporate Social

Responsibility (CSR) Dalam

Perspektif Pembangunan

Berkelanjutan. Fiat Justitia Jurnal Ilmu

Hukum Volume 7 No. 1. Lampung: Universitas Lampung.

Rachman, Nurdizal M., dkk (2011).

Panduan Lengkap Perencanaan CSR.

Jakarta: Penebar Swadaya. 